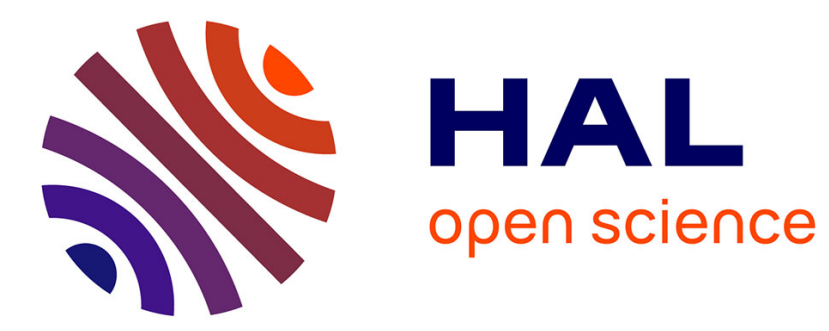

\title{
The weak-state cadastre: administrative strategies to build territorial knowledge in post-colonial Argentina (1824 to 1864$)$
}

Pierre Gautreau, Juan Carlos Garavaglia

\section{- To cite this version:}

Pierre Gautreau, Juan Carlos Garavaglia. The weak-state cadastre: administrative strategies to build territorial knowledge in post-colonial Argentina (1824 to 1864). Cartographica, 2012, 47 (1), p. 29-49. 10.3138/carto.47.1.29 . hal-00744777v1

HAL Id: hal-00744777

https://hal.science/hal-00744777v1

Submitted on 23 Oct 2012 (v1), last revised 5 Aug 2020 (v2)

HAL is a multi-disciplinary open access archive for the deposit and dissemination of scientific research documents, whether they are published or not. The documents may come from teaching and research institutions in France or abroad, or from public or private research centers.
L'archive ouverte pluridisciplinaire HAL, est destinée au dépôt et à la diffusion de documents scientifiques de niveau recherche, publiés ou non, émanant des établissements d'enseignement et de recherche français ou étrangers, des laboratoires publics ou privés. 
This document is the preprint of the following article:

Gautreau P. \& Garavaglia J C. 2012. The weak-state cadastre: administrative strategies to build territorial knowledge in post-colonial Argentina (1824 to 1864). Cartographica, Volume 47, Issue 1, 13-33.

\title{
The weak-state cadastre: administrative strategies to build territorial knowledge in post-colonial Argentina (1824 to 1864)
}

\author{
Pierre Gautreau \\ Panthéonn-Sorbonne University/ Laboratoire PRODIG/ UMR8586/ Paris/ France \\ J uan Carlos Garavaglia \\ Ecole des Hautes Etudes en Sciences Sociales/ Paris/ France Universitat Pompeu Fabra/ \\ Barcelona/Spain
}

\begin{abstract}
Studying the creation of administrations charged with devising land registers in the newly independent countries of Spanish-speaking America allows one to take an original view of statebuilding in these territories throughout the nineteenth century through models of "territorial knowledge"-building. The case of the "Topographic Department" of the Buenos Aires province between 1824 and 1864 is a textbook example of the successful strategies implemented by a very poor State to collect spatial information on a large scale over a huge territory - namely, by creating archives holding land survey maps. This study shows that the determining factor in the construction of state territorial knowledge was not so much the improvement of technical accuracy as the archival function and the definition of relationships between the administration and its agents. The building of administrations dedicated to collecting territorial data must therefore be understood as a complex process of devising norms relative to field techniques and practices, agents' behaviours in the field, and patterns of hierarchical relationships within these organizations.
\end{abstract}

Keywords: land register, land survey, state building, territorial knowledge, administration, Buenos Aires, Argentina

\section{I ntroduction: the individual-map-based cadastre as a weak-state strategy}

In this paper, we address the issue of how new states, which are economically dependent and have few revenue sources, develop one of the basic attributes of the modern state, i.e. territorial knowledge. In order to do that, we focus on 19th-century Argentina shortly after its independence. Territorial knowledge is studied here as the capacity to create and to permanently update a cartographic memory of land tenure, through high-resolution mappings of properties articulated into a cadastre of the Provincia de Buenos Aires. We will focus mainly on the strategies that a "weak" and recently independent state developed in order to overcome the obstacles to the improvement of its capacity to know and control land tenure.

From 1824 onwards, the Topographic Administration of the Buenos Aires province was responsible for helping the government with managing the highly sensitive and variable land-tenure situation, initiating an original cadastral program. While almost all the cadastres of European and AngloSaxon colonies during the 19th century were systematic and planned mappings of the territory (Nadal and Urteaga 1990, Kain \& Baigent 1992), the fragile economic situation of the Buenos Aires 
province prohibited similar ventures. Its administration did not send public employees for a systematic survey of the province's properties, but received and archived individual land-surveying maps from every landowner who wanted to establish his land-tenure rights.' It was therefore an "individual-map-based" cadastre, where the state's knowledge about its territory depended on the quantity of maps it received from the landowners of the province. We did not find any similar undertaking for the 17th, 18th or 19th centuries in Kain \& Baigent's (1992) huge historical survey of state-led cadastral projects. This constraint deeply challenged the building of territorial knowledge. First, knowledge was basically spatially incomplete since the administration only knew the places which landowners had mapped; second, the risk of heterogeneity between maps drafted by different land surveyors was high. Overcoming these difficulties supposed a capacity within the administration to articulate the different individual maps like the different parts of a puzzle, in order to build a complete panorama of land tenure in the province across space and through time.

This peculiar cadastre-construction process can be described as the strategy of a "weak state" to maximize knowledge-building with minimal investment. This was done in two ways. First, instead of financing large and costly teams of public land surveyors for systematic surveys, the Topographic Administration only validated a posteriori maps drawn by private land surveyors paid by the individual landowners. Second, its main financial investment was in archiving these maps, by building a repository of property titles. In this paper, we will focus on the first strategy: since the administration was unable to conduct the mapping of the properties by itself, it had to ensure the standardization of the techniques employed by land surveyors, so as to make the maps comparable and compatible for their incorporation to cadastre. But we will see that standardization was far more complicated in this situation than the mere elaboration of technical rules for mapping. The problem was, first of all, how to ensure the respect of these rules by land surveyors who were not public employees, and only indirectly dependent from the administration. We will observe how, over the period under study in this paper (1824-1864), the administration attempted to define the role of these particular agents by issuing regulations as well as through day-to-day administrative practices.

The focus of this research differs from other approaches of the relations between cadastre and state-building. The production of fine-scale and standardized maps by the administration may have improved the shaping of national representations, along with other instruments like the census, as mentioned by Benedict Anderson (1991), or by Hernán Otero (2007) in the case of Argentina. This movement was far from linear: using James C. Scott's words (Scott 1998) the attempts of the state to make its territory and population "legible" through mapping were strongly constrained by political and administrative fetters. The aim of this paper, then, is not to question the whole project of territorial mapping of the Argentinean state, but only the methods chosen to overcome the constraints for the gathering of high-resolution information within the Buenos Aires province, from the creation of the Topographic Administration in 1824 until the first complete cadastre of the province in 1864. This approach differs from - but doesn't contradict - most of the analyses that focus on the building of state power by studying the tensions between local and "national" powers which the cadastral process involves (Touzerie 2007). We mainly focus on the challenges at an administrative level to organize and to discipline a semi-independent body of land surveyors (the "gatherers" of local information). Even if , like others, we consider mapping as a "technology of power" in the Foucauldian sense (Dodds 1993, Harley 1988), we do not aim at understanding the direct effects of mapping projects on society, but the internal efforts of the state to assert its power of knowing the territory. Therefore, we do not analyse the content of the maps, but rather their production system. Likewise, we do not try and understand how "maps have become part of a wider political sign system" (Harley 1988), but rather how the state tried to make a system (a cadastre) from its fragmented knowledge over the territory (individual property maps). The 
methodological hypothesis we adopt is that the best path to analyze this particular level is to focus on the relations between the administration and land surveyors, in the way they interact and in the strategies the former applies to norm the techniques and behavior of the latter. Another peculiarity of this research is that it studies the links between the mapping administration and the statebuilding process in Argentina before the 1860 decade, whereas other research on this same topic addresses later periods (Lois \& Mastricchio 2010, Dodds 1993).

This study covers three main political periods of state development in independent Argentina. First, a liberal period of state organization, from 1810 to 1827 during the first steps of the state building process in the Rio de la Plata; then, the conservative period of 1830-1852 when Juan Manuel de Rosas, elected governor of the Buenos Aires province, developed an authoritarian government over the Buenos Aires province and reduced the entire state administration, significantly diminishing its size and expenditure on civil administration and concentrating on satisfying security and military needs; and lastly a new liberal period from 1852 to 1861, when the Buenos Aires province isolated itself from the other Argentinian provinces to form an independent unit (the Estado de Buenos Aires) and reorganized the state which had been disarticulated under Rosas. After 1861, the military victory of Buenos Aires against the other united provinces allowed for the unification of the provinces and the expansion of the state at a national level. Over these years, a growing portion of the land was incorporated through military expeditions to push back the Indian frontier toward the West, a process 1880 the end of the 1870s with the definitive defeat of the Indians.During this period, the Buenos Aires province was incorporated into the capitalist market, thanks to a strong control of property rights by the state, in order to secure and to organize the raising of cattle and the shipping of production over the pampas. This control of property was partly tied to the development of a topographical administration: as in other parts of the world, the cadastre was an "instrument for the extension and consolidation of power, not just of the propertied individual, but of the nation state and the capitalist system which underlies it" (Kain \& Bagent 1992).

In 1824, a short decade after Argentina became independent, the governor of the Buenos Aires Province, General Las Heras, created a Topographic Commission designed to establish the topographic map of the province. This Commission was soon replaced by the Departamento Topográfico in 1826, which had a national status. The establishment of this administration is closely related to the reform of the financial system of the province under the Rodríguez government (1820-1824), which guaranteed the province's public debt with public lands. From 1822 onward, it was prohibited to sell public lands, which were henceforth entrusted to private individuals under an emphyteutic lease (Banzato 2002). "The emphyteutic system, applied until 1840, made it necessary to establish a cadastre that could provide information about the state's pool of public lands. During a first phase, from 1824 to the 1830s, the Comisión Topográfica/Departamento Topográfico (hereafter DT) organized itself, and produced the first general cadastral map in 1830.iii Its activity declined dramatically during the second half of the 1830s and the 1840s, which saw the rise of General Rosas's power. ${ }^{\text {iv }}$ The DT reorganized itself and returned to a high level of activity in 1852, opening a second phase in the institution's organization under the "Estado de Buenos Aires" (D'Agostino 2007). This second phase, characterized by an increase in the DT's activity, reaching levels superior to those of the first phase, is linked with the reorganization and vast expansion of the state (Garavaglia 2007) after Rosas's defeat, to shifts in land legislation and to the emergence of private land markets which led to intensive changes in land tenure. ${ }^{v}$ Our study ends in 1864 , with the publication of the first cadastral map covering most of the legally owned territory of the Buenos Aires province. ${ }^{\text {vi }}$

Our main sources for this investigation are the compilation books of the DT's sessions ("Libros de actas") to be found at the Historical Archive of the Infrastructure Ministry of the Buenos Aires 
Province. In these books, the secretary detailed the questions, themes, matters, actions and debates within the leading group of engineers from 1824 to the end of 1860 . The total number of sessions is 737, mainly allocated within two periods: September 25, 1824 - June 28, 1834 (348 sessions) and January 15, 1857 - December 31, 1860 (357 sessions). Between these two periods, only 32 sessions, spread out in time, attest to the near-end of the DT's activities. After 1860, the huge amount of work led the DT to stop writing the proceedings of its sessions, except in cases of internal disagreements amongst its members. These documents offer a highly rich and complex material to explore the daily building of an administration, the tensions and relations between its members and with the outside actors of the newly independent Argentina (the government, the justice system, the pueblos...). It also offers a unique source to try and quantify the work done by this administration and its temporal variations. These data were supplemented by references to several other primary sources gathered in the Buenos Aires Province, in the city of Buenos Aires and in the Montevideo (Uruguay) historical archives. vii

The paper is divided into three parts. In the first part, we study the most important economic and technical features of the Topographic Administration. In the second section, we present the standardization of land surveying as the first strategy to improve the quality of the cadastre, and offer some clues to assess the effectiveness of this strategy. The third section addresses our main point: how the relations between the Topographic Administration and land surveyors evolve over the period, and are central to the administration's strategy. We argue that the "emancipation" of the administration from the land surveyors is a key point which marks the enhancement of the state's new territorial knowledge at the end of the period.

\section{A poor and busy administration gathering spatial information on land tenure}

The Comisión Topográfica, created on September 25, 1824, was transformed into the Departamento General de Topografía y Estadística on June 26, 1826. The "second" DT, which was reborn after the fall of Rosas during the 1850s, was given a general task by the government, who wanted to be "represented by the voice of clever men." "viii The most important of the DT's tasks was the establishment of a cadastre of the Province, although it was not the only one. ${ }^{\text {ix }}$ During the period under study, it repeatedly advised public authorities - the government and tribunals - on land-tenure and space-management questions by writing informes (reports). These informes had no legal value, but were used by these authorities to act and judge. On certain occasions, officers of the DT were "commissioned" to undertake specific cartographic works, like delimiting borders, roads or towns. The DT's cadastral activities included all the tasks related to the measurement and tenure evaluation of public and private lands, which meant regulating the technical and procedural aspects of land surveying, controlling every land survey map produced by the "public" land surveyors a posteriori, or drafting a general map of properties at the provincial scale (called Registro Gráfico, see Figure 1). Those general maps are the best documents to give us information about the archiving capacity of the administration, particularly its ability to knit together the individual maps received at the DT. As it clearly appears in Figure 2, the territorial knowledge gathered by the administration until 1833 was incomplete in its spatial coverage and heterogeneous in its quality. It was a direct consequence of the "individual-map-based" option already described in the introduction. From one session to another, DT officers shared between them the examination of all the individual land survey maps they received, and produced a report about each, either accepting the map or indicating problems in the technique or the procedure. These reports or informes were submitted to the vote of all the officers during the sessions, and when accepted - sent to the government. During the first period (1824-1834), these sessions were called the "Topographic Tribunal." 
Figure 1. Spatial progress in the cadastration of the Buenos Aires Province, from 1833 to 1864.

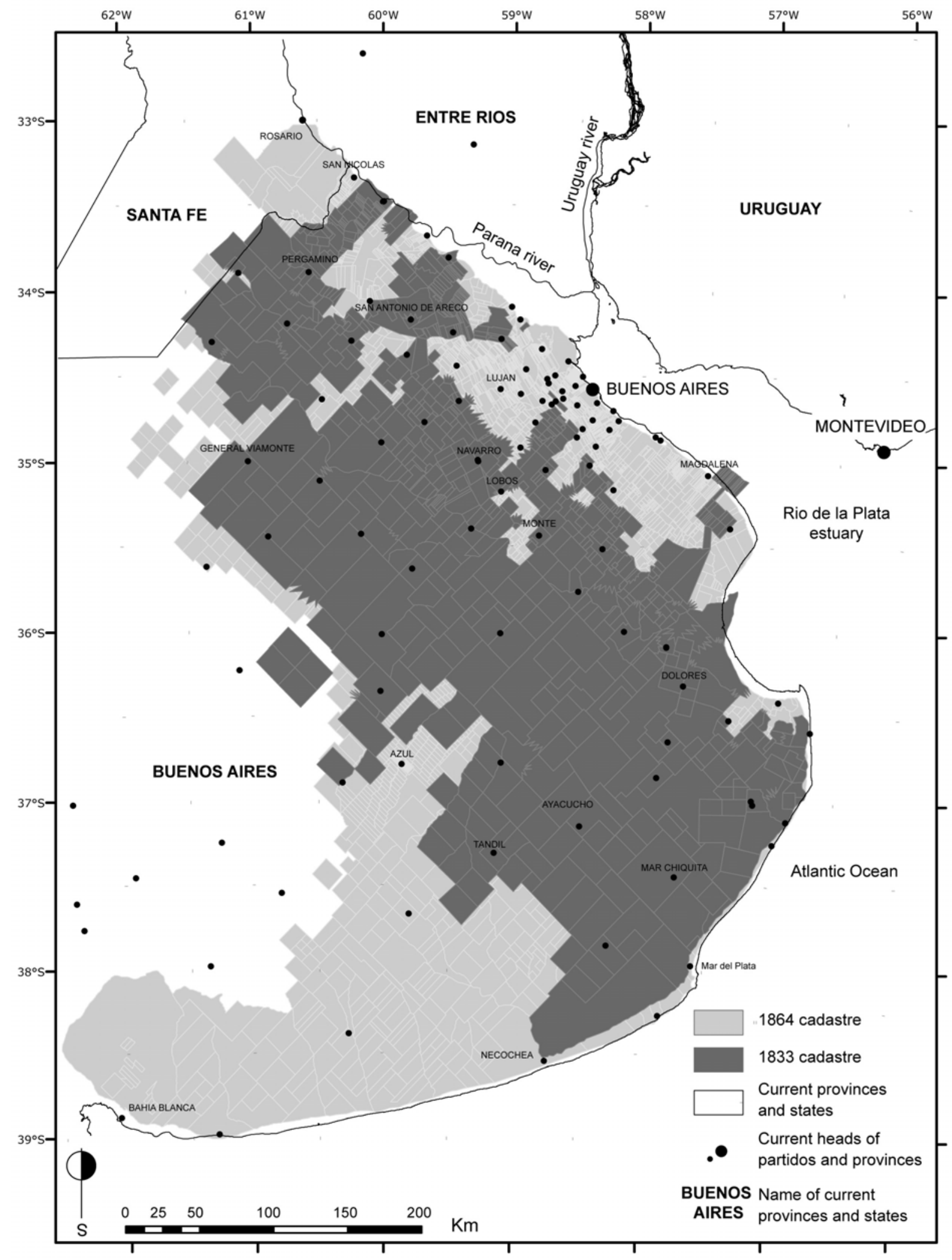

Source : digitalized from the original 1833 and 64 Registros Gráficos cadastral maps, Archivo Histórico de Geodesia y Catastro, Ministerio de Infraestructura, Provincia de Buenos Aires, La Plata.

Figure 2. Degrees of uncertainity in the 1833 cadastral map (Registro Gráfico). 


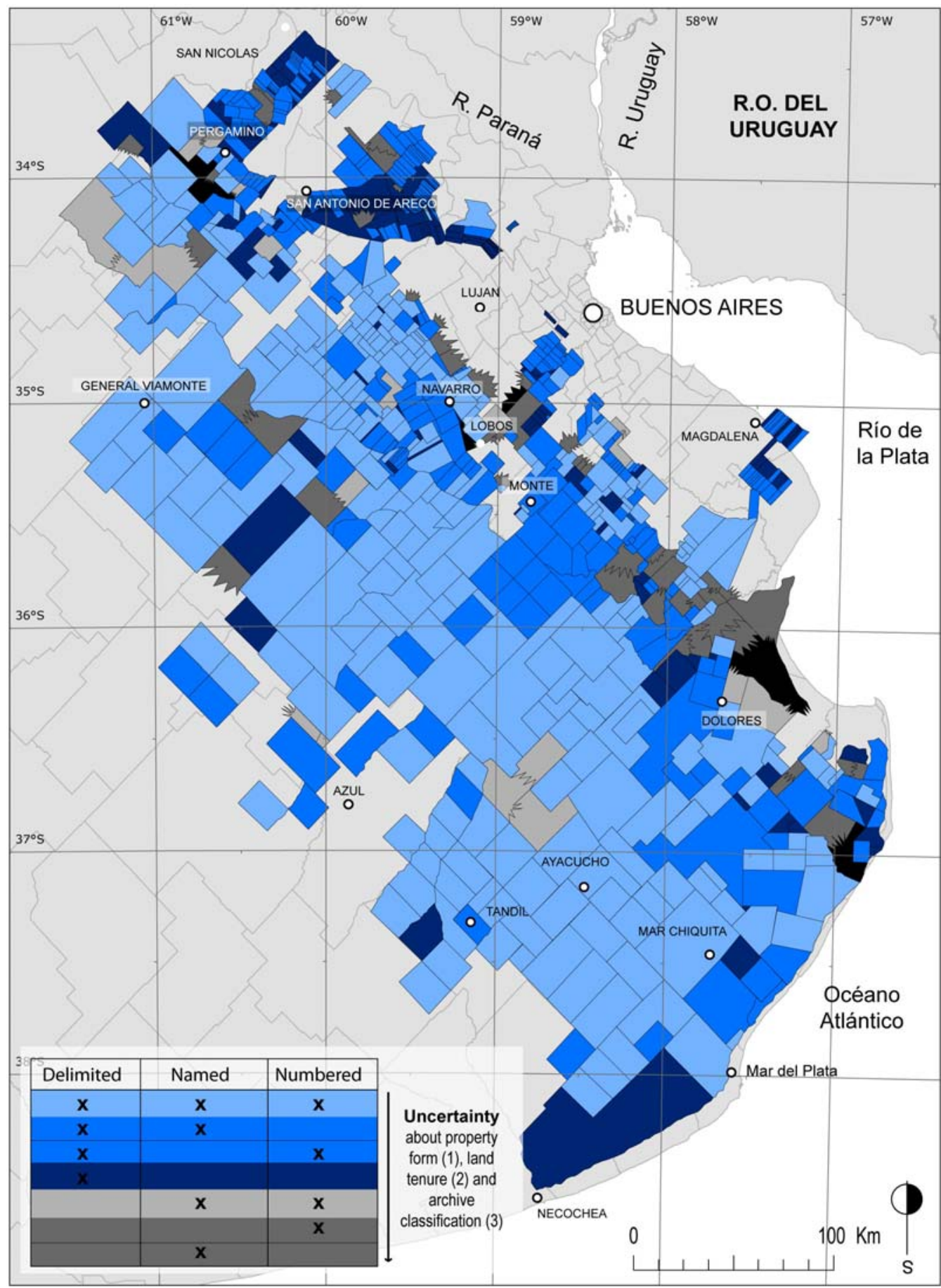

Source : Archivo Histórico de Geodesia y Catastro, Ministerio de Infraestructura, Provincia de Buenos Aires, La Plata.

The DT hierarchy evolved slightly during the period under study, in 1826 and 1858 (see Table 1), showing a slow progress toward specialization. At the top were the "engineers," who were responsible for the reports to the public authorities, discussed the best ways to improve the administration's work and organization, and formed the Topographic Tribunal. Their number increased from three to six during the period. The president of the DT was part of this first group. Decisions were taken by consensus, and even if the president had a stronger influence than the others, discussion and internal contests were not absent from Tribunal debates. A second group was formed by the oficiales, who generally worked outside the DT building, and their ayudantes (assistants). They did topographical works requested by the public authorities (comisiones), such 
as measuring and mapping roads, towns or streets inside and outside the city. Their number decreased from four to two during the period. A third group of employees dealt with the drawing and archiving of maps. After 1858, the functions of "Director of Drawing" and "Archivist," which belonged to this group but had previously been entrusted to the engineers, were created. Inside the DT office, the move to a higher echelon after some time was a normal and accepted way to advance in the hierarchy and to justify one's commitment to the tasks. ${ }^{x}$ This reinforced the feeling of belonging to a professional group, and ensured the development of an internal and homogeneous training of the employees. Among the other professionals involved with the DT's cadastral tasks were the "public" land surveyors, called agrimensores públicos, who only worked in the field. Even if they were not public employees, ${ }^{x i}$ most of their activities depended on DT instructions. They were chosen and paid by the private individuals who wanted to map their land, but could act only after a DT or justice decision. As we will see it later, the DT exerted an increasing control over the training of the agrimensores, was responsible for granting or refusing the "public" land surveyor license, and clarified the procedure they had to follow when surveying land. The number of active agrimensores públicos increased from 30 during the 1824-1834 decade to 91 during 1857-1867. Yet another group of professionals linked to the DT's activities were the topographic specialists in charge of comisiones (temporary works devoted to a single and well defined task) and of various cartographic works which the DT did not have the time or capacity to do.

Table 1 - Employee functions in the DT.

\begin{tabular}{|c|c|c|c|}
\hline 1825 & 1826 & 1842 & 1858 \\
\hline Presidente & Jefe & Presidente & Presidente \\
\hline Vocal primero & Ingeniero primero & Ingeniero segundo & Vice-presidente $\left(\mathrm{e} \mid \mathrm{ng}^{\circ} 1^{\circ}\right)$ \\
\hline Vocal segundo & Ingeniero segundo & Oficial primero & Ingeniero segundo \\
\hline Oficial auxiliar primero & Ingeniero secretario & Director de dibujo & Ingeniero tercero \\
\hline Oficial auxiliar segundo & Oficial primero & & Ingeniero cuarto \\
\hline Primer Ayudante & Oficial segundo & & Ingeniero secretario \\
\hline Segundo Ayudante & Oficial tercero & & Director de dibujo \\
\hline \multirow{4}{*}{ Delineadores (unknown nb.) } & Escribientes (2) & & Oficial primero \\
\hline & Delineadores (4) & & Oficial segundo \\
\hline & & & Oficial tercero y archivero \\
\hline & & & Delineadores (unknown nb.) \\
\hline$>8$ members & 13 members & 4 members & $>11$ members \\
\hline
\end{tabular}

Source: AHGC, Session proceedings of the Departamento Topográfico, and AGN-X-25-4-3, 1842 budget of Buenos Aires province. The data of 1825 is of the Comisión Topográfica. In 1842, the posts of ingeniero primero, secretario, oficial segundo, delineador Segundo and delinador cuarto are vacant.

The Topographic Department received a marginal part of the budget of the Ministry of Government (Departamento de Gobierno), a sum always inferior to 2\% of the total between 1824 and 1861 .Its relative importance in the budgets of 1841, 1854 and 1861 was the following: ninth budget item out of fifteen, tenth item out of sixteen, eleventh item out of sixteen. ${ }^{\text {xii }}$ This relative "poverty" may explain why public land surveyors were not public employees, and why the cadastre was "individual-map-based," and not fully done by the state. Nevertheless, its increasing budget reveals how important the DT had become for the government after the mid-19th century. The number of public servants increased from 10 in 1841 to 24 in 1861 (Garavaglia 2007). During the same period, the increase rate of the DT's budget was strikingly superior to the rate of the whole Ministry's budget. ${ }^{\text {iii }}$ Despite this improvement, the DT remained a small administration with a considerable workload, as the next figures will show. Figure $\mathbf{3}$ shows the number of sessions of the DT tribunal, when the engineers met and produced informes. From 1824 to 1829, the annual average number of sessions was around 50, it then fell to 15 from 1829 to 1834, and finally reached 85 during the 1857-1860 period. Figure 4 provides a more precise view of the variations 
of this activity: the average number of informes produced by session reached 10 in the 1857-60 period, where it had hardly exceeded 4 before 1834. The gap of 1829 is explained by the political troubles following General Lavalle's coup and the execution of Governor Manuel Dorrego. The near lack of sessions between 1834 and 1857 parallels the decay of all census-related activities under Rosas, who strengthened his grip over the state's activities and wanted to control his opponents' access to lands. As expressed by Hernán Otero (2007), "Statistics did not develop in any significant way during the Rosas period, partly for budgetary reasons, but also probably because administrative criteria and the peculiar management of the res publica by the Restaurador made the need for organizing a state department dedicated to collecting statistical data less necessary or urgent."

The shape of the DT's activities was then closely related to political and military trends. The southward expansion of the border to the detriment of the Indians during the 1820 s and the 1830 s, linked to the economic growth of agro-pastoral production in the Pampa, corresponded with the first peak of activity of this administration. The huge growth in activity after 1857 was driven by the effects of the progressive reorganization of the state (which started in 1852) and by an important economic renewal (Garavaglia 2007). Drastic changes in the land acquisition process the possibility of leasing public lands in 1857, the possibility of buying it after 1864 - and the development of dynamic land markets ${ }^{\text {xiv }}$ significantly increased the amount of informes about land transactions which DT officers had to examine during this period. This trend dramatically increased the workload of the engineers responsible for writing informes: they produced a monthly average of approximately 3.3 informes during the 1824-1826 period, 3.8 from 1824 to 1826, 16 in 1858, and 20 in $1860 .^{\mathrm{xv}}$

Figure 3. Activity of the Topographic Department: annual number of sessions.

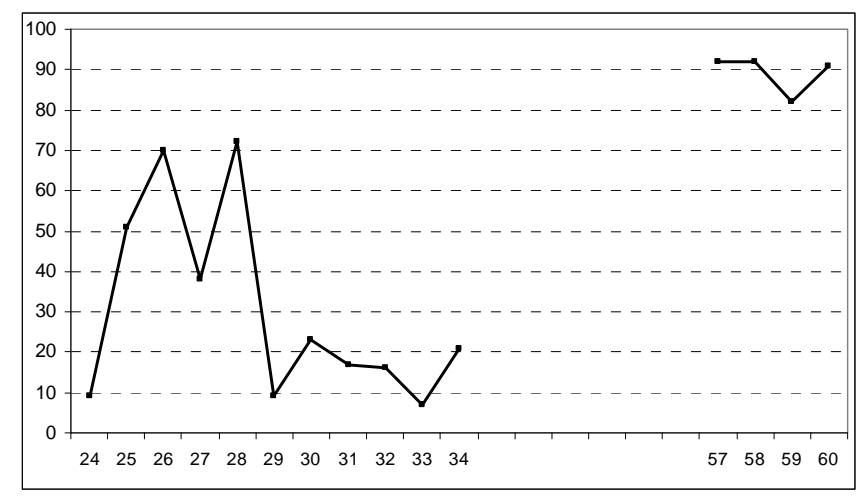

Source: AHGC, Session proceedings of the Departamento Topográfico.

\section{The standardization strategy}

The first consequence of the adoption of an individual-map-based cadastre was that the administration could not impose a priori the necessary standardization of the maps. Then, the control operated mainly a posteriori, by administrative validation of the maps. What was at stake with formal standardization was the social agreement to cadastration: to be acceptable for landowners, the process had to guarantee that everyone would have their land measured in the same way. Another vital point linked to standardization was to ensure the capacity for a reduced group of men to read and validate a growing number of maps, which had to be comparable. In such a difficult context, how did the DT develop its system of normalization and control of one of the main activities it had to regulate, namely land surveying? How did it produce criteria to 
distinguish between a good and a bad land survey? Which factors influenced these choices? In his letter to the government dated August 20, 1861, DT president Saturnino Salas expressed in concise words the essence of the administration's self-consciousness about its limited capacity to control the precision of land surveys. For Salas, although only the "uttermost scientific determination" of the limits of properties could be a warrant for their possession, ${ }^{\text {xvi }}$ the lack of funding prevented the administration from building a reference system which could ensure such accuracy of measuring (for example, installing an official network of precisely located boundary stones). Alternatively, the "best" way to improve precision was to lay down the rules land surveyors had to follow on the ground, regarding how to map a property and how to exchange information with the DT. xvii To put it briefly, a poor administration recognized that it could only do its best by evaluating the procedures followed by land surveyors a posteriori, based on written rules or "instructions." The next paragraphs describe the DT's efforts to develop such rules during the period under study.

Figure 4. Activity of the Topographic Department: monthly average number of reports written by session.

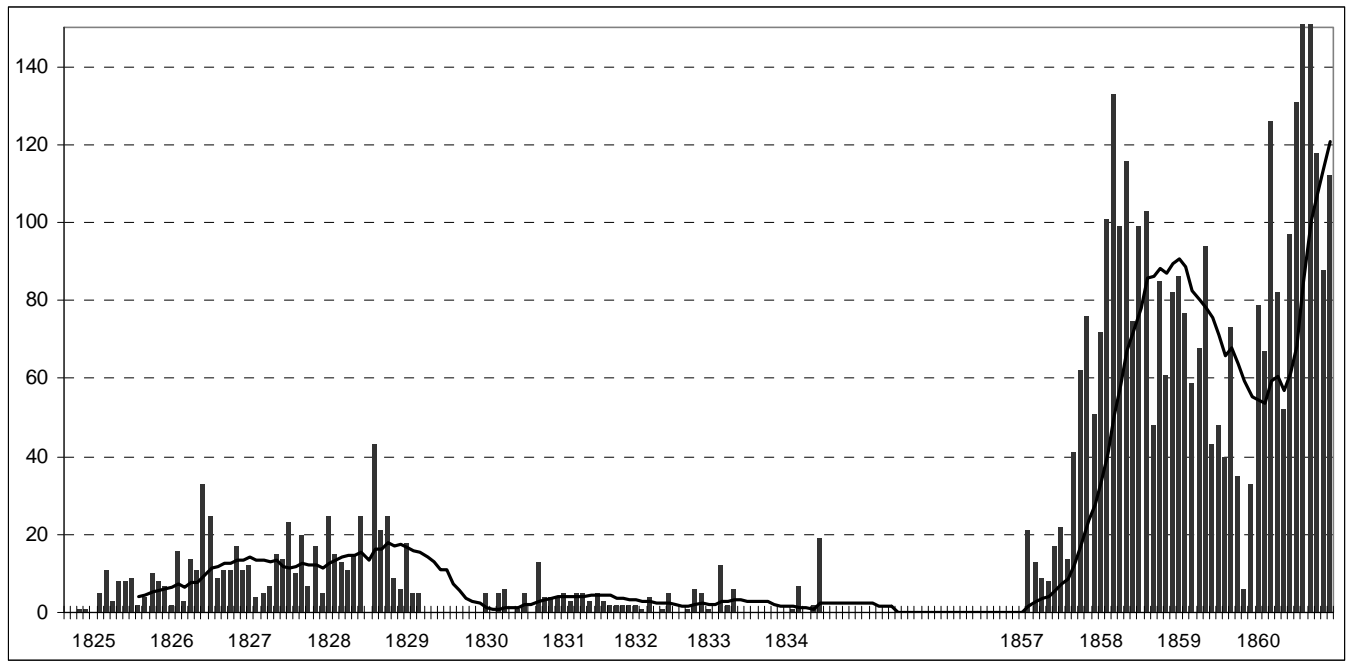

Source: AHGC, Session proceedings of the Departamento Topográfico. Line: moving average over 15 sessions.

The control and training of land surveyors

A first way to regulate land surveying was to create a system of technical references to improve the accuracy of the tools used for the surveys and for cartographic works in general. In 1825, an office was created where land surveyors could calibrate and verify the accuracy of their instruments (probably clocks and compasses) ${ }^{x v i i i}$ before they went in the field, and from 1826 onward they were even compelled to verify their tools. In 1828, a "meridian" was established as a reference for new surveys, ${ }^{\text {xix }}$ and in 1831 the DT engineers installed a vara "standard" - the $0.8666 \mathrm{~m}$ unit for lineal measurements - in the Buenos Aires Cathedral.

Only four months after the Comisión Topográfica was founded, the land surveyors' activities started being regulated by frequently updated Instrucciones. On January 1, 1825 the need to "homogenize" their working procedures by drafting a Reglamento was expressed, and the first engineer, Felipe Senillosa, was entrusted with this task. The document was published on April 21, $1825,{ }^{x x}$ and served as a reference to evaluate the land surveyors' work in later years. Further adjustments completed the instructions in 1835, 1839 and 1858. ${ }^{\times \times i}$ Finally, new instructions were published on September 28, 1861, a decade after the DT was reactivated. The comparison between 
the 1825 and 1861 instructions provides essential insights into the evolving aims of the DT's norming activity. The number of articles rose from 15 in 1825 to 68 in 1861, which shows that the DT wanted to control the work of land surveyors more precisely. The most striking evolution is the increase in articles defining the techniques which had to be used ( 5 out of 15 in 1825, 6 out of 9 in 1839, 21 out of 68 in 1861). A noticeable change in these technical articles from the 1820s to the 1860 s was the rise of articles norming the conduct of ground work, in comparison to those norming the drafting of maps (6 out of 11 articles in 1825 and 1839, 16 out of 21 in 1861). These changes show a clear trend toward the formalization and institutionalization of land surveying tasks.

The sanctions for failing to observe these rules were not frequent, but they existed. The years 1828-1831 seem to have been a "training" period as far as land surveyors' obedience to rules was concerned. Their reports were refused even before examination if the secretary noticed obvious non-compliance with the Instrucciones, an attitude common around 1828. ${ }^{\text {xxii }} \mathrm{A}$ re-measurement of the field was required on six occasions, ${ }^{x x i i i}$ and in one case the official status of a land surveyor was suspended for a year due to repeated inobservance of the rules. ${ }^{\text {xxiv }}$ During the DT's second period (after 1857), even when land survey maps were criticized, no obligation to redraft them was formulated: it could be hypothesized that as a group land surveyors had now accepted the working rules laid down by the administration and had internalized the standards set for their activity. This trend could be evidence of corporate apprenticeship on the part of public land surveyors.

This standardization was improved by the land surveyor training system which the DT progressively adopted. From the beginnings of the Comisión Topográfica, the title of agrimensor público was granted upon passing an exam, but its form stabilized only from the 1850s onward, when the DT was reorganized. ${ }^{x \times v}$ Until the 1830s, the "public" title was sometimes granted without an examination to men whose reputation and ability in land surveying was well-established by European diplomas or by practical experience in the region. In some cases, the DT hesitated to give a candidate the license to exercise without an examination, a proof that the land surveyor evaluation system was not standardized yet. After the $1850 \mathrm{~s}$, the most striking change was not only the systematization of the examination to become a public land surveyor, but also the strong requirement of "practice:" it became common around 1856 to ask the men who had passed a theoretical exam to confirm their ability by practicing for a few months with an active agrimensor público. This does not mean that after this year no license was given without an exam any more: it was the case for foreign land surveyors, mainly from Uruguay and Spain, and former DT engineers or officers. ${ }^{\text {xxvi }}$ Examination was then systematized mainly to guarantee the practical training of inexperienced candidates. The requirement of practicing with former professionals guaranteed the homogenization of both methods and work culture: during the second half of the 19th century, young land surveyors acquired their practical experience from a few very experienced men (namely Pedro Pico, Manuel Eguia and Teodoro Schuster). This probably played a crucial role in the standardization of working practices.

Another tool for work standardization was the creation of an Escuela Especial inside the DT that first started on March 1, 1857 to train young people who wanted to become land surveyors. ${ }^{\text {xxvii }}$ The early organization of this school was complicated, due to the low level of the students and to problems with teaching arrangements. The main question seemed to be that no specific budget existed to pay the teacher, who had to be chosen amongst active DT engineers, a point that limited school time to 2 hours a week. ${ }^{\text {xxviii }}$ Despite these problems, the creation of the school was an interesting experience, on account of its inclusion in an administration: the desire to compel employees to attend classes may be evidence of the first attempt to train public agents internally, and the school may rapidly have become a breeding ground for future DT employees. ${ }^{\text {xxix }}$ 
From "conscience" to "science:" technical normalization and the devising of criteria for a good land survey

Did implementing this set of norms lead to a measurable improvement of land surveys? A first way to measure this is to analyze the number of land survey maps that were rejected or "observed" by the DT tribunal, which means analyzing the reports that point out technical errors or noncompliance with procedures during the land surveying process. From 1824 to 1860, 145 maps were observed, out of a total of 1029 reports on land survey maps. Our hypothesis is that the lower the number of "observed" maps, the better we can imagine the ground work to have been. Figure $\mathbf{5}$ shows the percentage of observed maps over the total number of reports on land surveying maps produced by the DT. After a clear growth in observations from 1824 to 1831 , a decrease occurs during the succeeding periods (1831-1834 and 1857-1860). At first glance one could conclude that land surveyors as a professional group progressively accepted and incorporated the instructions and rules produced by the DT, following a process of corporate apprenticeship. In the beginning, during the years 1824-1831, the DT's severity was necessary to "train" an inexperienced body of land surveyors. However, it is necessary to nuance this interpretation that may erroneously support the idea of a continuous "progress" of the land surveying activity. Figure 4 indicates that after 1857 the DT had to face an unprecedented growth of its reporting activity that doubled (when including maps control) the average number of reports by sessions compared to the 1824-1834 period. Thus, a counter-interpretation of the trend observed in Figure $\mathbf{5}$ could be that the increasing workload of DT engineers meant a less thorough control of the quality of land survey maps. In the case of the 1831-1834 decrease in maps observation, the gradual disorganization of the DT can also be a key factor, due to the political effects of Rosas's rise to power. These observations do not allow us to conclude that the quality of land surveying improved greatly during the period under study.

Figure 5. Percentage of observed land-survey maps over the monthly total of land-survey maps reports (thin line); Percentage of land-survey maps reports, relative to the monthly total of reports written by the DT (thick line). Moving average over 15 sessions.

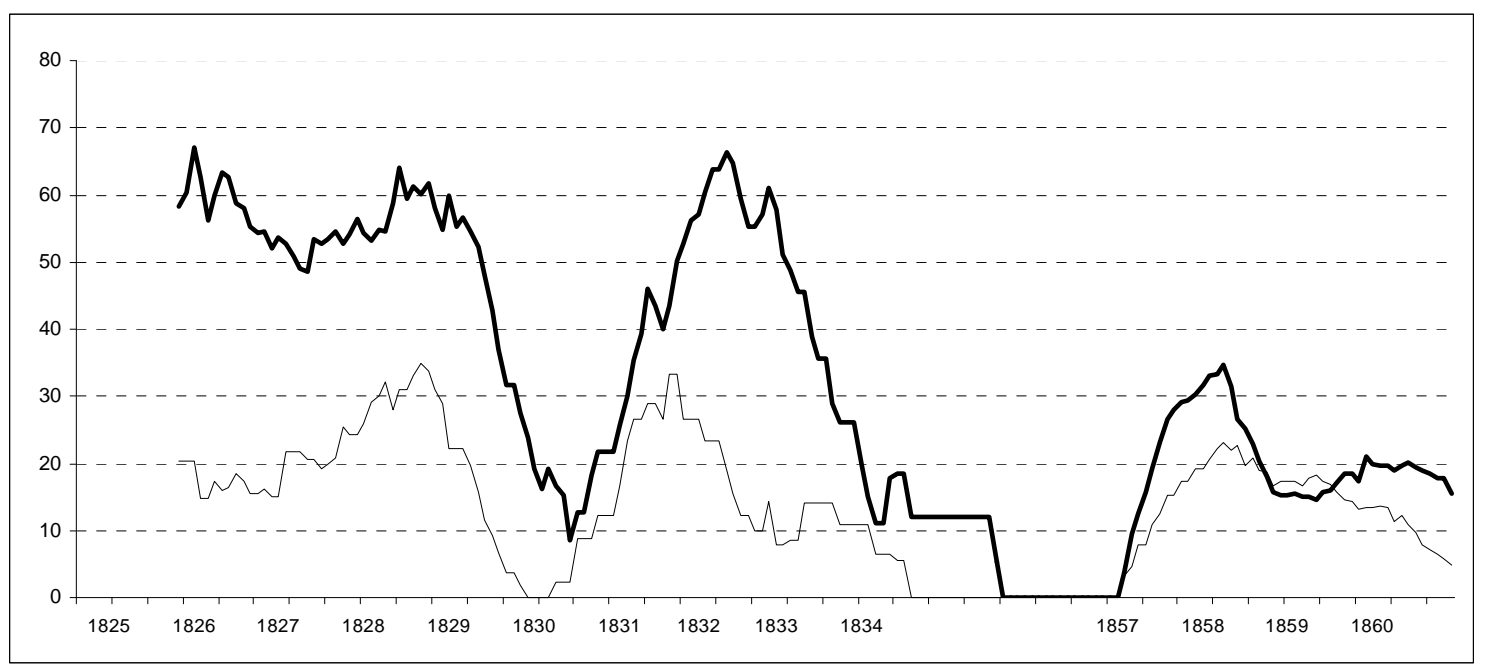

Source: AHGC, Session proceedings of the Departamento Topográfico.

To this quantitative analysis one can add a qualitative, temporal assessment of the criteria used to observe (i.e. criticize) land survey maps throughout the period. Three main types of criteria were used to observe a map: technical ones, related to the precision of measures; contextual ones, when the land surveyor did not bring enough information to localize the map within the larger territory; and procedural ones, when the land surveyor failed to respect some article of the 
Reglamento (mainly when the neighbors' compulsory assistance during the field measurement was not respected). ${ }^{x x}$ Over the whole period, only $18 \%$ of the maps were rejected for technical reasons, while $44 \%$ were rejected for contextual reasons, and $29 \%$ for procedural ones (and $9 \%$ for other diverse reasons). Figure 6 shows no specific trend in the use of these criteria over the period. The most striking element is the minority of maps observed for technical reasons for all years, except 1833 and 1857. These results do not support the idea of a high technical quality of land surveys; they rather show that the central point for the DT was to guarantee the social acceptance of land surveying measurements. The DT's interest was mainly to ensure that a field was properly located and that neighbors had accepted the measurement, rather than to obtain an accurate calculation of the area. The importance of the contextual criteria also shows the archiving concerns of the administration, which needed to know the precise location of a field within the territory, in order to rigorously process future land reports in the same region. "Precision" was not absolute, but relative to other fields. Then, we can hypothesize that the administration's main concern was to guarantee the "topological" accuracy of land surveys, i.e. the correct relative positions of the fields, rather than their absolute position or area.

\section{Figure 6. Relative importance of the criteria for the observation of land-survey maps.}

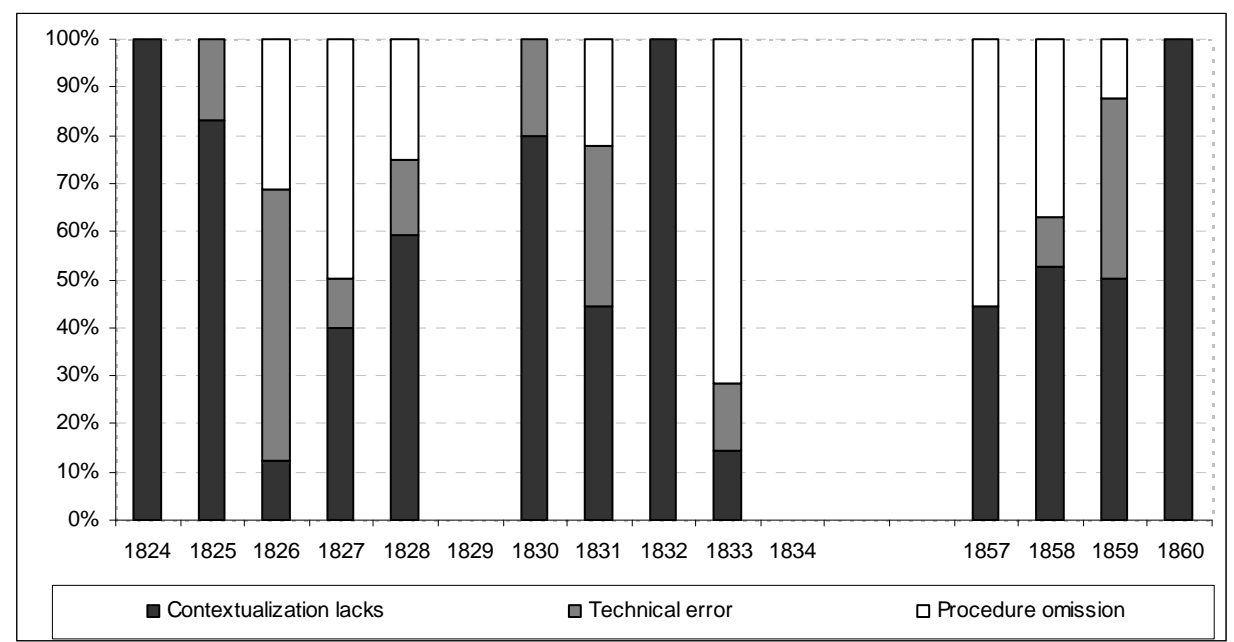

Source: AHGC, Session proceedings of the Departamento Topográfico.

Tolerance for technical carelessness in land surveys was common, and supports our hypothesis. In the consulted documents, we did not find a single reference to the ninth article of the Comisión Topográfica's creation decree (of September 1824) which defined the tolerable error range for land surveys. During the DT's first years, many land surveyors re-surveyed properties acquired under the colonial administration, and frequently found differences between their measurements and the form and area of the field calculated in the former property titles. Small differences were generally accepted by the administration. ${ }^{x x x}$ The priority for the DT was the measurement of "existing facts," xxxii i.e. the mapping of the effective limits between the occupants of the fields, rather than the redrafting of maps on the ground of fuzzy limits mentioned in former property documents. In a way, the task of land surveyors was to confirm the prior occupation of the land, rather than to verify whether existing limits exactly corresponded with legal titles. A fundamental issue for the DT was to guarantee that the neighbors of a measured field accepted the process: the main goal for land surveying was to reach a social consensus about property limits and the way they are established, as explained in the 1824 circular that asked all landowners to send their property titles to the Comisión: ${ }^{x x \text { xiii }}$ 
From the Comisión Topográfica to the landowners. Since the undersigned Comisión Topográfica will mainly be working in the countryside, and will require the full cooperation of the owners of chacras and estancias in said countryside, it seemed only fair to show them all the benefits they could derive from these operations and assure them that no alteration of their possessions will ensue, nor any cost or prejudice of any kind whatsoever. ... What has been the situation of countryside landowners to this day? A state of constant uncertainty.... These are serious problems ... which were bound to draw the government's attention. Being the only one to possess the means to set things right, the government had the important duty to protect properties and encourage industry. . . The situation of countryside properties will then change for the best! Old uncertainties will make way for security. Peace and harmony will erase the memory of tensions and litigations. . . ${ }^{x x i v}$

Even if we could not find any evidence of social resistance to cadastration in the archives - a frequent situation in modern Europe (Touzerie 2007b) - the cautious phrasing of the text may be proof that consent to this process (the sending of property titles and land surveying maps to the DT) was not always easy to secure. This helps us understand why contextual, and not technical, precisions were the main requirements for DT engineers. In a letter to the government dated August 28, 1826, DT leaders expressed their "conviction" that "most of the disputes" on land tenure were not due to the lack of technical quality of the measures, but to a lack of information about property titles and about the "extension and position" of neighboring fields. ${ }^{x x x v}$ It can be hypothesized that more significant changes in measurement accuracy occurred after the end of the period under study, accompanying, on the one hand, the rise in land prices and the organization of land markets in the wake of the 1860s laws which allowed the selling of public lands and, on the other hand, the progressive valorization of regional products on the international market. In this context, the improvement of property mapping must have arisen due to the social demand of the owners.

In the words of Napoleon Bonaparte (quoted by Kain \& Baigent, 1992) when he decided to undertake a systematic cadastre of France in 1807, "Half measures are always a waste of time and money. The only way forward is to survey the land in all communes of the empire, property by property". We can measure how distant from this modus operandi the cadastration process described here was, but it does not mean that the Buenos Aires province project was a failure. The goal of ensuring the social acceptance of state-sanctioned land occupation - the main objective was in fact reached by an effective control of land survey practices and the standardization of maps. The fact that technical improvement was not the core concern means that the administration adapted itself the impossibility to impose more accuracy in surveys and was aware that this was not crucial to the success of the process. This may be a proof of the effectiveness of this first strategy by a weak administration.

\section{The emancipation strategy}

The paragraphs below explore how the relations of the administration with its public employees and with public land surveyors - who were actually private agents - came to be defined. In our perspective this definition is much more than a simple device of administrative functioning. It represents a strategy to compensate the weakness of an administration which cannot send its own employees to map the properties - in brief, a political action. Our thesis is that the administration tried to clarify this relation, in order to reduce its dependence on agents who furnished the basic information for cadastration - the property maps. Expressed in a "co-productionist idiom", we analyze here, at the administrative level, "how knowledge-making is incorporated into practices of state-making .... and, in reverse, how practices of governance influence the making and use of knowledge" (Jasanoff 2004). These relations between the DT and its agents were not stable 
throughout the period, and its evolution shaped the global knowledge-building capacity of this administration.

Behavioral and bureaucratic definition of "public employees:" from rule to practice

The definition and division of tasks within the DT was a paradoxical process, revealing a tension between tendencies to differentiation and specialization, on the one hand, and recurrent factors that limited these tendencies, on the other hand. Amongst limiting factors, the indeterminacy and overlapping of tasks constituted a problematic issue. ${ }^{x x x v i}$ The internal regulations of 1825 and 1858 are representative of this paradoxical situation. In a way, these long documents of 30 and 51 articles tend to confirm a rising specialization of tasks inside this administration. The first Reglamento, presented on January 14, 1825, successively describes the "distribution of time in the Office" and the "obligations" of the president, engineers, officers and doorkeeper. The president was mainly in charge of organizing the timetable and splitting the work between the engineers and the officers, which basically amounted to dividing the reporting tasks and nominating officers for comisiones outside the office. He was responsible for every official decision of the Comisión Topográfica, and countersigned the texts it produced. Together with the president, engineers participated in the Topographic Tribunal (reporting on land survey maps) and controlled the daily work of subordinates. The first officer (oficial auxiliar) was in charge of the drawing of the cadastral map of the province (Registro Gráfico), while the second officer was at the same time secretary, instruments-keeper, treasurer and archivist. The 1858 regulations seem to follow this tendency toward specialization, by the creation of new individualized roles (Director of Drawing, Archive Engineer) and a more accurate description of preexisting roles. ${ }^{x x x v i i}$ Yet, both texts strongly remind the employees that they should accept and carry out tasks beyond their own role, and help each other in their tasks, a counter-proof of specialization, showing that multi-purpose dispositions were required from the employees. ${ }^{\text {xxxviii }}$ This requirement, which only concerned officers in 1825 , was extended to "every employee . . . indistinctly" in 1858, contradicting the idea of a linear and rising clarification of functions during the period.

This limited bureaucratization can be imputed to the reduced means of the DT and its lack of staff which made it compulsory for every employee to accept a wide variety of tasks and to limit their own specialization. Frequently, engineers had to take responsibility for a diverse number of tasks while the officers entrusted with cartographic works outside the office were absent. This relative fuzziness between functions and tasks may also be attributed to the characteristics of this particular technical group of employees, which was reduced in number, had strong daily interactions, was formed by cooptation and internal promotion (see some professional trajectories in Table 2), and where personal links and relations of professional allegiance were fundamental to one's progression up the administrative ladder.

Another important element in the bureaucratization process - and maybe an answer to the indeterminacy of functions - is the attempt to responsibilize employees. After Felipe Senillosa became DT president in January 1828, session proceedings began to describe more precisely how the reporting work was shared between engineers, and particularly started to name who was in charge of how many reports. In 1834, a seven-article document was adopted during a session that made it compulsory for engineers to countersign every report they wrote or analyzed, and forced the secretary to describe in detail the themes and documents discussed during the sessions. Thus, engineers constantly had to take responsibility for the decisions they made. Even though this process offered obvious symbolic benefits to the engineers, who could publicize their efforts within the DT (their work was now quantifiable), it also constituted a control tool for the administration, while the quantification of the amount of work they undertook allowed the engineers to negotiate 
with others the sharing of the tasks. ${ }^{\text {xxix }}$ Such a purpose is also manifest in the case of subalterns: in 1828 a registry of absentee employees was established in order to "appreciate everyone's merit."xl

Table 2. Professional trajectories of some important members of the topographic administration.

\begin{tabular}{|c|c|c|c|c|c|c|c|c|c|}
\hline FUNCTION & $\begin{array}{c}\text { Senillosa } \\
\text { Felipe }\end{array}$ & $\begin{array}{c}\text { Arenales } \\
\text { José }\end{array}$ & $\begin{array}{c}\text { Díaz } \\
\text { Avelino }\end{array}$ & $\begin{array}{c}\text { Salas } \\
\text { Saturnino }\end{array}$ & $\begin{array}{c}\text { Pico } \\
\text { Pedro }\end{array}$ & $\begin{array}{l}\text { Gutiérrez } \\
\text { J uan-M. }\end{array}$ & $\begin{array}{l}\text { I bañez } \\
\text { Agustín }\end{array}$ & $\begin{array}{c}\text { Moreno } \\
\text { Mariano }\end{array}$ & $\begin{array}{l}\text { Eguía } \\
\text { Manuel }\end{array}$ \\
\hline Inspector & 1857.02 & 1829.02 & 1830.03 & $1852 *$ & & & 1858.03 & & \\
\hline Presidente & 1828.01 & $\begin{array}{l}\text { - circa } \\
1850.10\end{array}$ & 1830.03 & $\begin{array}{c}- \\
1875\end{array}$ & & & & & \\
\hline $\begin{array}{l}\operatorname{lng}^{\circ} 1^{\circ} \\
\text { Ing }^{\circ} 2^{\circ}\end{array}$ & 1824.09 & 1828.01 & $\begin{array}{l}1824.09 \\
1825.03\end{array}$ & & $\begin{array}{l}1856.07 \\
1855.08\end{array}$ & & & & \\
\hline Ing $^{\circ}$ Secret $^{\circ}$ & & & & & & 1829.02 & 1826.07 & & \\
\hline Oficial primero & & & & 1828.05 & & $\begin{array}{c}1828.01 / \\
1834.02\end{array}$ & 1825.12 & 1859.02 & \\
\hline $\begin{array}{l}\text { Oficial segundo } \\
\text { Oficial } 3^{\circ} \text { archivero } \\
\text { Ir ayudante (1826) } \\
2^{\circ} \text { ayudante (1826) } \\
\text { Escribiente ( } 1858) \\
\text { Delineadores }\end{array}$ & & & & $\begin{array}{l}1826.05 \\
1826.07 \\
1825.12\end{array}$ & & $\begin{array}{l}1826.05 \\
1825.12 \\
1826.07\end{array}$ & & $\begin{array}{l}1825.12 \\
1827.01\end{array}$ & $\begin{array}{l}1826.05 \\
1826.07 \\
1825.12\end{array}$ \\
\hline Public land-surveyor & & & & 1834.04 & $\begin{array}{c}1834-41^{*} \\
1858.12\end{array}$ & 1857.01 & 1853.11 & 1831.07 & $\begin{array}{c}1834 \\
1835^{*}\end{array}$ \\
\hline
\end{tabular}

Source : AHGC, Session proceedings of the Departamento Topográfico). The date - month and year corresponds to session proceedings, and does not always correspond to the beginning of the function. Bold text: function created after 1826. Bold and italic text: function created after 1858. Parenthesis: year when the function disappears. * Registry of an activity as public land-surveyor in Uruguay, according to the Graphic Archive of the Ministerio de Transporte y Obras Públicas, Montevideo.

Indeed, several documents allow us to perceive both a formal and an informal disciplining process amongst DT employees. Some norms were accepted and promoted early on in the core activity of land survey control, so as to ensure - at least formally - an administrative impartiality: the engineers in charge of the reports did not participate in the evaluation of maps or land-tenure cases when they had a private involvement with the case, and this was carefully written down in the sessions registry. ${ }^{x l i}$ But until the 1860s, DT authorities clearly failed to find a way to "moralize the subordinates of the Department" and to impose an internal discipline. From the beginning, the same problems affected the daily activities of the office: the slowness of the work, the lack of respect for the timetable, and behavioral issues like absence at work. In 1857, the proceedings from a session during which measures were taken to control the employee responsible for the reception desk stated that it was prohibited to "undertake private work at the office, to leave the desk during working hours," and hinted at problems of postmarked paper embezzlement. ${ }^{\text {xlii }}$ Even the establishment of an internal inspection function, held in turn by the engineers, could not significantly reduce behavioral problems, and its failure "made the Department's authority a laughing matter even for its own subordinates." "xliii These repeated attempts to impose discipline were closely related to the attempt to defend the DT's reputation and "good name," as the president reminded staff in 1827. xliv Indeed, the state and the DT authorities attempted to control public employees' behavior outside the office, by compelling them to attend important religious or civic ceremonies and to develop civic feelings, for example by pledging allegiance to the Constitution of the state in 1854. These continuous attempts to internally discipline the employees of the DT were partly applied to the land surveyors, the other group of professionals working in the cadastration process.

Defining the relations with land surveyors: how the administration "shaped" its agents 
It is important to focus our study on the status of public land surveyors because it reveals some of the peculiarities of the administration-building process in early Argentina. Land surveyors were not public employees but had the monopoly of surveying private properties. Their status was implicitly defined when it was stated that Topographic Commission officers - i.e. public employees - were forbidden to measure private fields. ${ }^{x / v}$ Land surveyors were paid by landowners, but their work the mapping of both public and private fields - was strongly controlled by the state, i.e. by the topographic administration. This situation probably revealed the state's inability to pay for their salaries, and may be another proof of the poverty of this early independent state (war was the main preoccupation of the Rosas government). The Comisión Topográfica's founding decree defined land surveyors as totally dependent on this administration, although they had no hierarchical or administrative links with it. Land surveyors were strictly controlled by the Comisión: from 1824 onward, no land survey could be valid without the Comisión's agreement (art. 4), land surveyors needed the Comisión's authorization to practice their profession (art. $5 \& 6$ ), had to follow the Comisión's instructions, and had to specify to the Comisión the procedures they followed in the field (art. $7 \& 8$ ). They had to draw a standardized map for every land survey they made (art. 14) and send a countersigned copy to the Comisión archives (art. 15). Finally, the Comisión expressed its opinion when landowners contested a measurement or when land surveying mistakes had been made (art. $11 \& 16$ ). In short, public land surveyors were the heirs to colonial "measurement judges" (art. 12), their measurements had a judicial value, but they were strongly dependent on the topographic administration. This paradoxical strong dependence of non-public employees was confirmed in 1826, when the Departamento Topográfico took the place of the Comisión and was put in charge of the "examination, licensing and guiding" of land surveyors. ${ }^{x l v i}$ The definition of the land surveyors' job by the administration even included their remuneration, meticulously established in February 1825, ${ }^{\text {xlvii }}$ and the list of persons authorized to exercise this profession was published in both official and private journals, probably with a view to preventing the illegal exercise of the profession.

The complex relationships between land surveyors and the topographic administration underwent significant changes between the "first period" (1824-1834) and the second one (from 1857 onward). Gradually, the profession of land surveyor became more clearly defined (D'Agostino 2007) and the dependence toward the DT increased as far as certain tasks were concerned. Before the 1850s, the status of public land surveyor was not clearly established, even for DT members, who decided to consult the government in 1828 to clarify whether these men were "public employees". xlviii The close proximity of tasks and training between surveyors and DT employees, and the fact that several individuals shifted status over the course of a career, contributed to reinforcing such indeterminacy. It was common that a land surveyor left his job to join the DT, and vice-versa, as Table 2 shows for some members who reached a high status. ${ }^{x i x}$ Apart from the presidents of the DT's first period, the highest ranking employees up to the 1850s used to alternate between land surveying and administrative positions (Saturnino Salas, Pedro Pico, Mariano Moreno), or left the DT to become land surveyors (Juan María Gutiérrez, Agustín Ibáñez, Manuel Eguía).

Individual and professional proximity was even stronger during the first period of the CT/DT (18241834). For a number of years (1828 until 1831 at least), a succession of land surveyors integrated the Topographic Tribunal to help it with its tasks, "while some of its members were absent." The land surveyors were chosen by the DT authorities, then the government confirmed this choice, and, after having been sworn in, they started to evaluate the topographic works of their colleagues, like every other public employee used to do. These daily practices and exchanges may have created feelings of belonging to a single profession, close to the state's administration, and made the 
frontier between "public employees" and "public" land surveyors thinner. Until the end of the 1830s, the DT was unable to carry out all the tasks which the needs of the period compelled it to undertake without the assistance of the land surveyors. A very significant part of the cartographic comisiones - temporary mapping works ordered by the DT - was entrusted to surveyors because DT officers were too few to carry them out by themselves. Some archiving tasks in the office were also temporarily done by land surveyors. ' It is interesting to notice that land surveyors and officers (i.e. DT employees) frequently worked together on the ground, an essential point to develop professional solidarities.

After the reactivation of the Topographic Department in the 1850s, this peculiar situation significantly evolved toward a clearer distinction of functions. The number of comisiones given to land surveyors was dramatically reduced and there were attempts by the DT to make its relationships with land surveyors more formal, a process which generated tensions. In 1858, a major controversy erupted within the DT, which consulted the government to know whether it could "dictate" to the land surveyors what they had to do in the field, an arrangement which some of those men refused. The secretary regretted that the DT "did not regulate its relationships with land surveyors," because the old regulations were "extremely incomplete." The government argued that land surveyors had to strictly follow DT instructions. The 1861 instructions, strongly oriented toward a greater and stricter control of the land surveyors' activities, confirmed the victory of the secretary's position: out of 68 articles, 21 defined the relationship between the DT and land surveyors. It is not surprising that this controversy opposed the current DT engineers to those of the same generation as inspector Felipe Senillosa, who had died three months before. This former president was the heir of the 1830s period, when relationships between land surveyors and the DT were much more about cooperation than about execution. In a posthumous letter read during the debate, Senillosa defended the idea that the DT could only control land surveyors on technical aspects, but could not influence their "judgment."li

In 1858, in line with this controversy, land surveyor Don José Maria Romero complained to the government about the "arbitrary" actions taken by the DT against him. "lii In 1859, another controversy, this time involving land surveyor Jaime Arrufo, closed with the wish to be stricter with "land surveyors." "liii In this process, a kind of "emancipation" of the DT from the government may have been an important factor. In June 1857, DT president Saturnino Salas contradicted inspector Felipe Senillosa, who wanted to submit updated "instructions" for land surveyors to the government: the former felt that the DT could act alone in this matter, and did not need to refer to the government. liv One of his arguments was that the DT had acquired through "practice" the administrative knowledge that enabled it to judge and act in such matters. This strong claim of an emancipated administrative "ethos" probably induced the Department to emphasize the differences between DT employees and land surveyors. The DT needed, for its own administrative and symbolic purposes, to distance itself from these formerly "semi-public" employees.

Nevertheless, this interpretation would be incomplete if we only took into account behavioral or political factors to explain the rising formalization and distinction of functions between the DT and land surveyors. Another key factor the inversion of power relations between land surveyors and the DT - is scrutinized in the following section.

Trends in the social repartition of territorial knowledge: a "power inversion" theory between land surveyors and the administration

One last way to explore the relations between the DT and the land surveyors is to analyze how mapping knowledge was shared between these two groups, and how it evolved over time. From a 
theoretical point of view, in administrations specialized in the gathering of spatial information, there is a radical asymmetry in the type of knowledge possessed by the field workers (land surveyors in our case) and the administration (the DT). The former possess a local knowledge, while the latter possesses a global knowledge, derived from its archiving activity. We can therefore say that during the first years of a cadastral administration, territorial knowledge is concentrated in the hands of the land surveyors: every man knows the regions he mapped empirically better than the administration does, as the administration only possesses a fragmented knowledge formed by the few land surveying maps archived in its repository. Over time, there is an inversion of knowledge sharing. The knowledge of the administration, progressively formed by years of archiving local maps, is far more precise and richer than the individual knowledge of each land surveyor. The administration is then able to establish relations between hundreds of old and new maps, to accumulate multiple details about the territory, while land surveyors cannot "record" more information than an individual memory can.

When the topographic administration began, the state was somehow "blind:" it had no precise field-based knowledge about the limits and the ownership of properties - the Comisión Topográfica was specifically created to address this problem. In such a context, land surveyors were the only possessors of this precious knowledge. Although dispersed between several individuals, topographic local knowledge was in fact their monopoly. It then makes sense that the topographic administration should have been accommodating to those men on whom it depended for its global task. After the 1850s, the situation was the exact opposite: the DT had a huge archive of land survey maps - 653 in 1834, 1735 in 1861, 4153 in 1870 (Ministerio de Obras Públicas 1945a) and a long practice of global analysis of the territory. The land surveyors' cooperation was no longer needed as much as during the 1830s. In a way, the power struggle was reversed: thanks to its archives, the DT had a much broader knowledge than land surveyors and a better capacity to check the accuracy of their work. It is not surprising that in such a situation, relationships became much more formal and hierarchized.

The 1858 debate between Senillosa's posthumous position and the engineers of the office can be interpreted as a conflict between two conceptions of cadastre-building. Senillosa thought that it was fundamental to preserve the independent production of a field-based knowledge by the land surveyors, without any disruption by the administration during this process (for example, sending instructions while measurements were being done in the field). ${ }^{\mathrm{I}}$ On the other hand, Ibáñez, the current inspector, and other members thought that the DT often had a "complete knowledge of the facts" and "knew the localities perfectly." This newly legitimated archival knowledge led them to claim that the DT had a higher authority and should guide land surveyors in the field. Obviously, this second option imposed itself in the 1860s, with profound consequences for the rearrangement of the links between the topographic administration and land surveyors.

So as to deepen this analysis, we offer in Figures $\mathbf{7}$ and $\mathbf{8}$ an evaluation of the repartition of "knowledge" amongst land surveyors during the period under study. Our hypothesis is that the more experienced the land surveyors were, and the more concentrated the activity of mapping was amongst a small number of them, the more dependent on them the DT was. An administration is more independent on its field agents when each of them possesses a small piece of local knowledge and when he has little experience. "Experience" was calculated as the sum of the years of activity in land surveying for every land surveyor, and "concentration" of mapping knowledge was calculated by dividing the sum of maps surveyed by the total number of active land surveyors during a year..$^{\text {lvi }}$ Figure 7 shows that land surveyors as a group accumulate mapping experience regularly during the period, reaching 420 cumulated years in 1864, despite a slower increase in the number of active land surveyors (from 20 to 60 over the period). This trend demonstrates the 
rising experience of land surveyors as a group, and is linked to the rising demand for land surveying, and the attractiveness of this job (the turn-over of land surveyors is low, and it allows the multiplication of veterans of the profession). But this global trend is not observable in Figure 8, which assesses the individual experience and concentration of knowledge. Until the end of the DT's first period, the individual experience of land surveyors is rising: when $50 \%$ of them had more than 5 years of experience in 1829, in 1839 they were $50 \%$ to have more than 12 years of experience. During this first period, each land surveyor concentrates on average $12 \%$ of all maps surveyed each year. After 1852, the situation is completely reversed. Due to the multiplication of land surveyors and the massive rise of annual surveys, both individual experience ( 5 years as a median value) and knowledge concentration (2-3\% of all maps surveyed each year) decrease significantly. These observations support our hypothesis of a significant inversion in the relations between land surveyors and the DT after 1852, due to a shift in the repartition of knowledge. As a group, land surveyors had more experience after 1852 than before 1840. But each of the land surveyors concentrated less experience, and a greater part of the group was formed by novice professionals. This change may have allowed the administration to strengthen its control over land surveyors.

To conclude this section, we can say that the emancipation of the administration from its agents appears as a key process which signals the ability of the administration to overcome one of the consequences of the individual-map-based cadastre model: its dependence on land surveyors. This process followed several convergent paths: a more accurate definition of the land surveyor by the topographic administration during the period in order to clearly differentiate the different professional groups and hierarchies, a political tendency to control the field practice of land surveying, and finally a "mechanical" inversion of knowledge repartition in favor of the administration.

Figure 7. Temporal evolution of cumulated experience of the land-surveyors group and of the number of active land-surveyors.

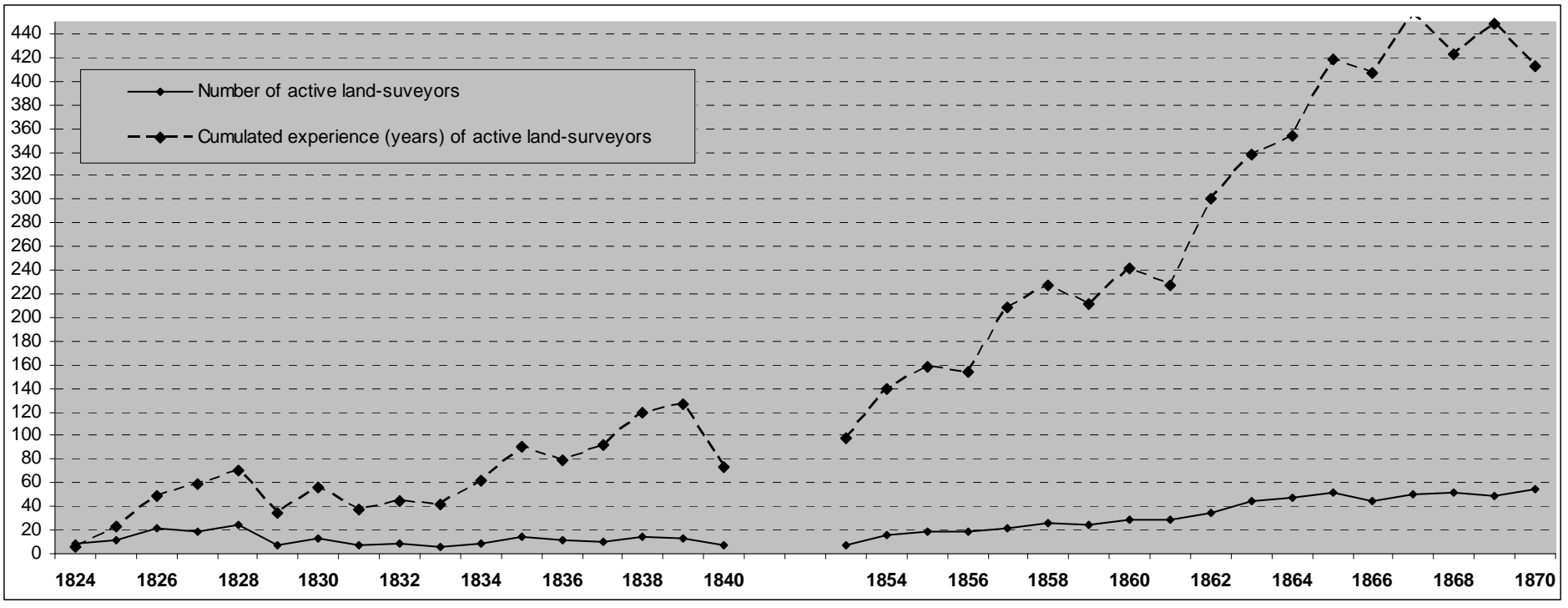

Source: Catálogo General de Mensuras de la Provincia de Buenos Aires, 1824-1944 (Ministerio de Obras Públicas de la Provincia de Buenos Aires. 1945a).

Figure 8. Temporal evolution of concentration of territorial knowledge amongst the land-surveyors group. 


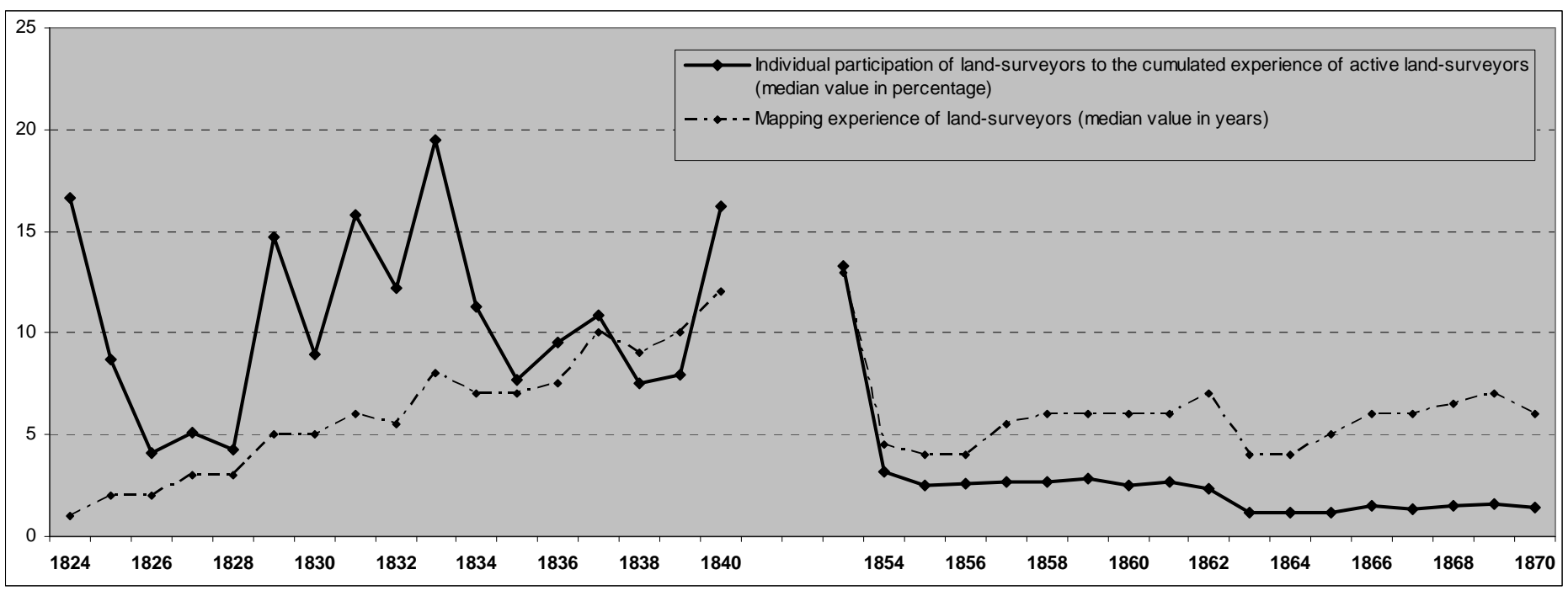

Source: Catálogo General de Mensuras de la Provincia de Buenos Aires, 1824-1944 (Ministerio de Obras Públicas de la Provincia de Buenos Aires. 1945aa).

\section{Concluding remarks}

In spite of the many obstacles to the expansion of the cadastre over the province, it is impressive to observe how a handful of poorly-equipped men were able to gather and organize information about a large territory which almost reached $130,000 \mathrm{~km}^{2}$ during the $1860 \mathrm{~s}$, culminating in a complete coverage of delineated lands in 1864. ${ }^{\text {Ivii }}$ It becomes all the more impressive when considering that the same amount of time ( 40 years) was needed by the much more equipped and better financed Frenchmen who completed the first version of the Napoleonic cadastre, and that part of the delay on the Argentinian side is due to the intensity of military conflicts. In fact, the strategies developed to face the challenges of an individual-map-based cadastre were successful. It was more than an ingenious plan to maximize the profitability of a small budget; it was a model of state adapted to periods of scarcity, especially for the beginnings of an independent state when war and the tax system were the main economic concerns.

This model, which was developed under tremendous constraints, may explain the capacity of the administration to organize itself and to last in spite of political troubles and long periods of nearinactivity (the 1840s). The DT's experience, from the 1820 s to the $1870 \mathrm{~s}$, shows the success of a simple but efficient strategy to collect and interpret spatial information gathered by land surveyors. The DT's rapid reactivation after 1852 and the fall of Rosas proves that internal norms of organization and working practices, mainly established before 1835 and fully accepted by the members and collaborators of the administration, ensured the continuity of the office and made it capable of responding to the needs of the rising land-tenure changes from the 1870s onward. During the 1850s, finally, the administration's capacity to strengthen its independence and to differentiate itself from land surveyors may be another fundamental sign of the building of a modern administration.

Two important remarks from Jeremy Black (2008) about the relations between mapping and statebuilding in modern Europe allow us to underline some important points involved in the cadastration of the Buenos Aires province during the period considered in this paper. First, he warns against the risks of making overly strong parallels between state-construction and the progress of mapping. The case we described here certainly shows strong parallelism with other contexts where surveys "made landscape understandable to a central bureaucracy" (Craib 2001, 2000), or where "the 
creation of geographical knowledge has been closely bound up with the emergence of the modern state" (Dodds 1993). We nonetheless pointed several pre-modern dimensions of the topographic administration which took several decades to disappear. The fragmentation of territorial knowledge, the dependency on land surveyors, the non-differentiation of functions amongst employees... Administration- and state-building were not parallel and continuous processes. Another pre-modern dimension can be seen in the fact that Rosas was easily able to deactivate the DT during the 1840 decade, while not experiencing any problem to assert his control over the territory: the state has many ways to know the territory other than mapping.

Secondly, Black insists that the rising demand in Europe for precision in measurements was rather a response to social demands than a result of internal administrative initiatives, a insight also applicable to the Buenos Aires case. What was it in the activities of the Departamento Topográfico from 1820 to 1870 that provided the state with the decisive tools for the consolidation of its power? In fact, the spatial progression of mapping (the cadastre covered $108,900 \mathrm{~km}^{2}$ in 1833 and $181,500 \mathrm{~km}^{2}$ in 1864) was not accompanied by any drastic change in land surveying accuracy and methods. Thus, the key point for the administration was its archiving capacity: the DT did not directly map the rural grounds but mainly gathered the maps drafted by land surveyors, determined their localization within the territory, and analyzed relative positions between neighbors. This building of an administrative memory of territorial knowledge was far more innovative and decisive for the state than the mere fact of increasing the precision of mapping, which for the period under study should not be stressed as a key problem. Archiving, much more than mapping, was the actual invention of a weak and young state.

\section{Acknow ledgments}

The authors thank Juan Pro and Mariana Canedo for helping us to improve this manuscript. This research was fund by the project "State Building process in Latin America (1820-1870)", FP7/20072013 / ERC grant agreement n²30246.

\section{Notes}

\footnotetext{
' In 1825, a decree made it compulsory for every landowner to send his property title to the Comisión Topográfica (Libro de Actas, Archivo Histórico de Geodesia y Catastro, Ministerio de Infraestructura, Provincia de Buenos Aires, La Plata, session of 22 June 1825).
} 

ii The emphyteusis was established by the decree of 1 July 1822, modified and extended to the whole country
on 27 June 1826 (Registro Oficial de la Provincia de Buenos Aires, Años 1824-27, Buenos Aires, 1879).
iii Registro Gráfico de los terrenos publicos y particulares de la Provincia de Buenos Aires, 25 Sept. 1830,
Archivo Histórico de Geodesia y Catastro, Ministerio de Infraestructura, Provincia de Buenos Aires, La Plata.
iv This decline did not mean a total paralysis, but a drastic reduction of the total number of land survey controls
and mapping tasks in general (Recalde 1999, Esteban 1962).

$\checkmark$ Public Land Leasing Law (1857) and Public Land Selling Law (1864, 1867, 1871). For an overview of this question over the entire period, see Valencia 2005 and Infesta 2003.

vi Registro Gráfico de las propriedades rurales de la Provincia de Buenos Aires construído por el Departamento Topográfico y publicado con la autorización del superior Gobierno de la Provincia, 1864, Archivo Histórico de Geodesia y Catastro, Ministerio de Infraestructura, Provincia de Buenos Aires, La Plata.

vii AGN: Archivo General de la Nación. AGN-DT, legajos X-14-3-2, X-42-10-1, X-43-3-2 (miscellaneous documents from the Comisión Topográfica and Departamento Topográfico). AHGC: Archivo Histórico de Geodesia y Catastro, Ministerio de Infraestructura, Provincia de Buenos Aires, La Plata. AHGC-L1: Libro de Actas (session proceedings of the Comisión Topográfica and Departamento Topográfico from 1824 to 1857). AHGC-L2: Libro de Actas, Dirección de Geodesia, Asesoría Histórica, no. 171 (session proceedings from 1857 to Aug. 1859). AHGC-L3: Libro de Actas, Dirección de Geodesia, Asesoría Histórica, no. 172 (session proceedings from Sept. 1859 to Dec. 1860). AHGC-DAE: Documentos Antiguos y Expedientes (miscellaneous documents from the Comisión Topográfica). AHPBA: Archivo Histórico de la Provincia de Buenos Aires, "Ricardo Levene," Ministerio de Educación, Secretaría de Cultura, La Plata. AHPBA-DT (miscellaneous documents from the Comisión Topográfica and Departamento Topográfico). ROPBA: Registro Oficial de la Provincia de Buenos Aires, Años 1824-27, Buenos Aires, 1879 (compilation of laws and decrees).

viii Letter to the DT from Valentín Alsina, Governor of Buenos Aires (AHGC-L1, 2 Apr. 1852).

ix The Comisión Topográfica and the DT were in charge of the Registro Estadístico de la Provincia de Buenos Aires (book of statistics) until 1827. After 1853, a new independent Mesa Estadística de la Provincia de Buenos Aires was created, but the DT continued to provide it with information, as did other administrations (Otero 2007).

× The DT carefully controlled the progression of its employees within the hierarchy: in 1828, a comisión was given to a foreign land surveyor, provided that "it did not alter the order of promotions within the office" (AHGC-L1, 15 May 1828).

xi In 1838, Hidalgo Joaquin was forbidden to exercise as agrimensor público, because he was a soldier at the same time: "because exercising land surveying is incompatible with the status of public servant, in all state administrations" (AHGC-L1, 30 Nov. 1838).

xii According to data from Garavaglia, "Construyendo el estado".

xiii Between 1841 and 1854, the increase rate of the DT's budget was $860.2 \%$, when the increase rate of the Ministry's budget was $443.9 \%$. Between 1854 and 1861, the respective numbers were $109 \%$ and $61.9 \%$ (calculation in pesos-fuertes, based on data provided in Garavaglia, "Construyendo el estado," 2007).

xiv From 1823 to 1840 , the main way to acquire public land was through an emphyteutic lease. Donations by the authorities, under different forms, were in use from 1829 to 1852, as well as sales after 1836 (Marta Valencia, Tierras públicas, tierras privadas). After Rosas's defeat in Caseros (1852), the Province authorities attempted to clarify the intricacy of many land-tenure situations in a context of frequent unofficial possession by unofficial possessors or occupants of the land. This process may have participated to the increase of land transactions the DT had to examine.

${ }^{x v}$ As an illustration of this trend, the first engineer complained about the internal allocation of work in 1857 , denouncing the fact that he had to "examine [land maps] daily, which he did outside office hours (since otherwise he could not have gone to the Departamento), to give land surveyors [the necessary instructions], to provide watchmakers with the time, which compelled him to set the clocks, and finally to examine files like all other members" (AHGC-L1, 7 July 1857).

xvi "On account of the quality of our soil, so poor in natural objects which could be used as limits between properties, limits in their present state are but mere lines traced by the land surveyor, which constantly change position depending on the proprietors' whims or bad faith. ... We will therefore guarantee land ownership by ensuring the strictest scientific determination of such unstable limits." (Letter from Saturnino Salas to the Ministro Secretario de Gobierno, Dr. Pastor Obligado, 20 Aug. 1861, in Ministerio de Obras Públicas de la Provincia de Buenos Aires, Dirección de Geodesia, Catastro y Tierras, Instrucciones Generales para Agrimensores [La Plata: Taller de Impresiones Oficiales, 1945, $2^{\text {nd }}$ ed.].)

xvii Ways to improve the accuracy of land surveys were: "a better regulation of the procedures which land surveyors had to follow . . . land survey reports written up [as clearly as possible], which are a supplement to and the best explanation of property titles, and the archiving of these reports by the Department." (Letter from Saturnino Salas to the Ministro Secretario de Gobierno, Dr. D. Pastor Obligado, 20 Aug. 1861, in Ministerio de Obras Públicas de la Provincia de Buenos Aires, Instrucciones Generales para Agrimensores, 1945.)

xviii Reglamento Interno de la Comisión Topográfica, articles 13 to 17, AHGC-L1, 14 Jan. 1825. In 1827, a french technician was paid (comisionado) to improve the quality of these tools (AHGC-L1, 23 Feb. 1827).

xix AHGC-L1, 4 Mar. 1828. This meridian is probably the "Buenos Aires" meridian, used as the " 0 " meridian in the Argentinean maps of the nineteenth century at least until 1864. According to an internal report of the Instituto Geográfico Militar, its longitude is $58^{\circ} 22^{\prime} 14.445^{\prime \prime}$ South (18 Dec. 1937, Informe respecto al meridiano $0^{\circ}$ de Buenos Aires, al Presidente de la Comisión Técnica de límites interprovinciales, archives of the Instituto Geográfico Militar Argentino).

xx AGN, Nacional, legajo V-XV-9-2, in Ministerio de Obras Públicas de la Provincia de Buenos Aires, Instrucciones Generales para Agrimensores, 1945.

xxi Ministerio de Obras Públicas de la Provincia de Buenos Aires, Instrucciones Generales para Agrimensores, 1945. 
xxii AHGC-L1, 18 Aug. 1828: "Following the recurring failure to observe several articles from the instructions to land surveyors, the Secretary was asked to refuse any file which did not meet the required conditions."

xxiii AHGC-L1, 10 May 1825, 9 Mar. 1827, 14 Aug. 1827, 23 Aug. 1827, 21 Jan. 1831, 26 June 1831.

xxiv AHGC-L1, 19 Dec. 1832.

$x x v$ Even if there had been some intention to improve examination methods before 1830 (AHGC-L1, 28 Apr. 1826), we have no document proving that it was done. During the DT session of 6 May 1828, a change in the land surveyors' examination was called for.

xxvi This being said, some clues tend to indicate that there was a tendency in the DT to require an exam even for well-known professionals. In 1858, the fourth engineer criticized the president for licensing an experienced man: "from now on the Department should exclusively adopt the examination system, which is both more formal and more appropriate" (AHGC-L2, 21 May 1858).

xxvii AHGC-L1, 17 Feb. 1857. The special school was created after the 14 Jan. 1857 decree (AHGC-L1, 4 Feb. 1857).

xxviii AHGC-L2, 25 Feb. 1858.

xxix On 24 Aug. 1858, the young students of the Lagos \& Martell School were offered to join the DT as "aspirants" (AHGC-L2).

${ }^{x \times x}$ Examples of the criteria used for the observation of maps are presented here. Technical criteria: failure to mention the difference between the magnetic and geographical North in the land survey report; the map does not follow the "prior" limits of the measured field. Contextual criteria: the land survey report does not indicate precisely how the starting point was determined. Procedural criteria: the neighbors were not asked to witness the measurement; they were summoned but the report does not indicate whether they were present and approved the measurement; the owner of the field did not bring any titles or documents before the measurement was taken.

xxxi Several examples of this tolerance can be found in the archives: AHGC-L1, 4 Mar. 1828, 10 Apr. 1826, 26 Mar. 1825, 10 Apr. 1826, 7 July 1826, 13 July 1827, 11 June 1827, 23 Jan. 1830, 17 Sept. 1830, 20 Mar. 1832, 21 Jan. 1831, 6 Mar. 1857, 26 June 1857, 9 Dec. 1857; AHGC-L2, 9 Apr. 1858, 9 Dec. 1857, 9 Feb. 1858.

xxxii AHGC-L2, 3 Sept. 1857.

xxxiii These titles were then "extracted" by the officers, who drew an approximate sketch of the property according to the textual information they contained.

xxxiv Primera Circular de la Comisión Topográfica, 1824, AHPBA, Departamento Topográfico, legajo 1, 49-2-1-20. ${ }^{x x x v}$ AGN, Gobierno Nacional, Departamento de Ingenieros, legajo V-XVI-6-7.

xxxvi In 1826, the second engineer Romero regretted that the employees did not limit their activity "exclusively" to their own functions (AHGC-L1, 17 Mar. 1826).

xxxvii The number of articles per function in the 1858 regulations was the following: president, 6 articles; vicepresident and other engineers, 12; secretary, 5; first official, 1; second official, 3; archive official, 7; drawers, 1; manager of documents reception, 1; doorkeeper, 4. The "Rules and Regulations of the Departamento Topográfico" were approved in January of that year (AHGC-L2, 20 Jan. 1858).

xxxviii Article 26 from the 1825 regulations: "To the obligations to which auxiliary officers must submit are added those of helping each other and of undertaking the extraordinary tasks which the Commission might entrust to them . . . either in the office or outside the office, be that in the city or the countryside." (AHGC-L1, 14 Jan. 1825.) Article 49 of the 1858 regulations: "no employee will be permanently affected to any position among those specified by the present regulations, being understood that [the Department] can change or alternate the positions held by employees according to circumstances or necessity. All employees without distinction will have to help each other and switch positions in order to usefully carry out any task the Department will give them." (AHGC-L2, 20 Jan. 1858.)

xxxix See the complaint of an engineer who wanted to be given less work in note 15, AHGC-L1, 7 July 1857.

${ }^{x l}$ AHGC-L1, 21 June 1828.

xli Engineer Felipe Senillosa deliberately avoided expressing his opinion in land tenure disputes occurring in an area where he owned fields (AHGC-L1, 20 Apr. 1825) or when he "shared a friendship" with one of the parties (with Rosas, AHGC-L1, 17 Dec. 1828). He left the room when his land surveys were analyzed or when he personally knew the owners (AHGC-L1, 7 Jan. 1825, 17 Feb. 1826, 21 Feb. 1826, 23 Jan. 1828).

xlii AHGC-L1, 26 Mar. 1857.

xliii AHGC-L1, 2 J une 1857, 1 J une 1858; AHGC-L2, 26 Feb. 1858, 15 Apr. 1858.

xliv AHGC-L1, 4 June 1827.

xIv AHGC-LI, 22 Mar. 1825

xIvi ROPBA-1824-27, Buenos Aires, 109-10, article 3.

xlvii AHGC-L1, 8 Feb. 1825. The proceedings of this session detail in eight articles the amounts that have to be paid depending on the characteristics of the and the time to be spent surveying fields depending on distance to the city. The payment was made by the owners, who had to compensate the transport and accommodation fees of the land surveyor and his assistants, and bring personal help to measure the field. The fixing of public fees was one way to limit the risk of unofficial negotiations between the land surveyor and the landowner.

xlviii The government's response is unknown, but the DT's opinion was that they were indeed public employees. It is not clear whether this position was determined according to legal considerations, or supported by strategic administrative objectives: public employees were exempted from milicia service (AHGC-L1, 23 Jan. 1828). In a letter of 22 Mar. 1825, the secretary of the Ministry of Government assimilates land surveyors to "public persons" (Ministerio de Obras Públicas 1945b).

xlix Less well-known DT members were also land surveyors before they joined the office or became land surveyors after they left it ( 10 cases are known during the period).

'From 1825 to 1834,25 comisiones are mentioned in the session proceedings (AHGC-L1).

"i AHGC-L2, 7 July 1858. 


\footnotetext{
Iii AHGC-L2, 2 July 1858, 6 J une 1857.

liii AHGC-L2, 28 jan. 1859.

liv "Mister president signaled that the instructions from 1825, supplemented by later decisions, had been modified by the Department so as to introduce changes which practice had shown to be necessary. He did not see fit to submit these changes to the government since the Department, as stipulated in the institution's founding decrees, had the right to guide land surveyors in the practical aspects of their duties." (AHGC-L1, 2 June 1857, underlined in the original text.)

Iv His letters insist that the DT can only "orientate" the land surveyors "in the matter of scientific procedures but can by no means affect or coerce the land surveyor's judgment about operations of localization." Considering the Department's lack of data, it cannot "prescribe a priori what must be done when taking a land survey measurement." On the contrary, the DT would endanger its authority, because it "should never issue a definitive judgment" (AHGC-L2, 7 July 1858).

Ivi Calculation from a statistical analysis of the Buenos Aires province catalog of land surveying maps (Ministerio de Obras Públicas de la Provincia de Buenos Aires 1945).

Ivii Estimation of Garavaglia 2004, based on data from the Registro Estadístico del Estado de Buenos Aires, vol. 3 (Buenos Aires, 1856), 15.
}

\section{References}

Anderson, B. 1991. Imagined Communities: Reflections on the Origin and Spread of Nationalism. London: Verso.

Banzato, G. 2002. Ocupación y acceso a la propiedad legal de la tierra en la región nordeste del Río Salado: Chascomús, Ranchos y Monte, 1780-1880. PhD diss., Universidad de La Plata. Available online: http://www. fuentesmemoria.fahce.unlp.edu.ar/te.17/te.17.pdf.

Black, J. 2008. "Government, State, and Cartography: Mapping, Power, and Politics in Europe, 1650-1800". Cartographica 43/2: 95-105.

Craib, R.B. 2001. State Fixations, Fugitive Landscapes: Mapping, Surveying and the Spatial Creation of Modern Mexico, 1850-1930. New Haven: Yale University Press.

Craib, R.B. 2000. "Cartography and Power in the Conquest and Creation of New Spain". Latin American Research Review 35/1: 7-36.

D'Agostino, V.A. 2007. “Los orígenes de la agrimensura como profesión: su relación con el Estado y el régimen de propiedad de la tierra (provincia de Buenos Aires, primera mitad del siglo XIX). In Cuestiones agrarias en Argentina y Brasil, eds. N. Girbal and S. de Mendonça. Buenos Aires: Prometeo Libros. 271-88.

Dodds, K-J. 1993. "Geography, Identity and the Creation of the Argentinean State". Bulletin of Latin American research, 12/3: 311-331.

Esteban, F. 1962. El Departamento Topográfico de la Provincia de Buenos Aires. La Plata: author edition.

Garavaglia, J.C. 2007. "El despliegue del estado en Buenos Aires: de Rosas a Mitre". In Construyendo el estado, inventando la nación: EI Río de la Plata, siglos XVIII-XIX. Buenos Aires: Prometeo Libros.

Garavaglia, J.C. 2004. "La propiedad de la tierra en la región pampeana bonaerense: algunos aspectos de su evolución histórica (1730-1863)". In En busca de un tiempo perdido: La economía de Buenos Aires en el país de la abundancia, 1750-1865, eds. R. Fradkin and J.C. Garavaglia. Buenos Aires: Prometeo Libros.

Garavaglia, J.C. 2003. "La apoteosis del Leviathan: El estado en Buenos Aires durante la primera mitad del siglo XIX". Latin American Research Review 38/1: 135-68.

Harley, B. 1988. "Maps, knowledge and power". In The iconography of landscape: Essays on the Symbolic Representation, Design and Use of Past Environments, eds. D Cosgrove \& S Daniels. Cambridge: Cambridge University Press.

Infesta, M.E. 2003. La Pampa criolla: Usufructo y apropiación privada de tierras públicas en Buenos Aires, 1820-1850. La Plata: Archivo Histórico de la Provincia de Buenos Aires.

Jasanoff, S. 2004. "The Idiom of Co-production". In States of Knowledge: The Co-production of Science and Social Order, ed. S. Jasanoff. New York, London: Routledge. 1-12.

Kain, R.J.P. \& Baigent, E. 1992. The cadastral map in the service of the State. A history of property mapping. Chicago: The University of Chicago Press. 
Lois, C \& Mastricchio, M. 2009. “Una historia de la Cartografía Argentina”. In IGM 130 años IGN, L. Weisert, Instituto Geográfico Nacional, Buenos Aires.

Ministerio de Obras Públicas de la Provincia de Buenos Aires. 1947. Manual de disposiciones usuales para la Dirección de Geodesia, vol. 1, Antecedentes de la repartición y archivo. La Plata: Taller de Impresiones Oficiales.

Ministerio de Obras Públicas de la Provincia de Buenos Aires. 1945a. Catálogo General de Mensuras de la Provincia de Buenos Aires, 1824-1944, Archivo de la Dirección de Geodesia, Catastro y Tierras. La Plata: Taller de Impresiones Oficiales.

Ministerio de Obras Públicas de la Provincia de Buenos Aires 1945b. Instrucciones Generales para Agrimensores. La Plata: Taller de Impresiones Oficiales.

Nadal, F. and Urteaga, L. 1990. “Cartografía y Estado: Los mapas topográficos nacionales y la estadística territorial en el siglo XIX". Geocrítica 15/88. Available online: http://www.ub.es/geocrit/geo88.htm.

Otero, H. 2007. Estadística y nación: Una historia conceptual del pensamiento censal de la Argentina moderna, 1869-1914. Buenos Aires: Prometeo.

Recalde, J.M. 1999. Evolución de la función social de la Agrimensura en el Río de la Plata: Aportes para una historia de la Agrimensura. La Plata: Biblioteca del Agrimensor.

Scott, J.C. 1998. Seeing like a State: How Certain Schemes to Improve the Human Condition Have Failed. New Haven: Yale University Press.

Touzerie M. 2007a. «De l'estime au cadastre en Europe: L'époque moderne ». Conference Proceedings, 4-5 Dec. 2003. Paris: Comité pour l'histoire économique et financière de la France.

Touzerie M. 2007b. “Cadastres en Europe à l'époque Moderne: Modèles continentaux et absence anglaise ». In De l'estime au cadastre en Europe: L'époque moderne, ed. M. Touzerie. Conference Proceedings, 4-5 Dec. 2003. Paris: Comité pour l'histoire économique et financière de la France. 1-8.

Valencia, M. 2005. Tierras públicas, tierras privadas: Buenos Aires 1852-1876. Buenos Aires: Editorial de la Universidad de La Plata. 